\title{
Continuous Improvement and its Barriers in Electrical and Electronic Industry
}

\author{
Md Fauzi Ahmad ${ }^{1, *}$, Toh Li Yan ${ }^{1}$,Chan Shiau Wei ${ }^{1}$, Ahmad Nur Aizat Ahmad ${ }^{1}$, Raja \\ Zuraidah Raja Mohd Rasi ${ }^{1}$, Nor Aida Abdul Rahman ${ }^{2}$,Nik Hisyamudin Muhd Nor ${ }^{3}$, Mohd \\ Fahrul Hassan ${ }^{3}$,Fatan Adibah Hashim ${ }^{4}$
}

${ }^{1}$ Faculty of Technology Management, Universiti Tun Hussein Onn Malaysia, Malaysia

${ }^{2}$ Faculty of Aviation Management Department, Universiti Kuala Lumpur Malaysia Institute of Aviation technology (UniKL MIAT), Malaysia

${ }^{3}$ Faculty of Mechanical and Manufacturing Engineering, Universiti Tun Hussein Onn Malaysia, Malaysia

${ }^{4}$ Sharp Manufacturing Corporation Malaysia, Malaysia

\begin{abstract}
Continuous improvement is one of the core strategies for manufacturing excellent and it is considered vital in today's business environment. Continuous improvement is an important factor in TQM implementation. However, manufacturers in Electrical and Electronic Industry is facing variety of challenges such as, time constraint, quality issue, headcount issue, human issue and competition in domestic as well as the global market. This paper presents total quality management practices in Electrical and Electronic (EE) Industry. These manufacturers have to keep improving in key activities and processes to cope the challenges. Therefore, EE industry realize the importance of continuous improvement in helping the industries by setting clear goals and priorities for the area of improvement. The aims of this study are to determine the main factor in implementing continuous improvement practices, identify tools of continuous improvement that have been used and their obstacle in implementing continuous improvement practices. 200 questionnaires had been distributed to the employees in Electrical and Electronic Industry located at Bayan Lepas, Penang, Malaysia. A total of 41 questionnaires were answered which represented about $20.5 \%$ response rates. Survey result shows that teamwork and training and learning are respectively the importance factor and the most practices factor in Electrical and Electronic Industry. Most of the Electrical and Electronic Industry emphasis is on using Lean Manufacturing as the tool of continuous improvement practices. Besides that, Electrical and Electronic Industry faced the problems of lack of budget and lack of worker commitment.
\end{abstract}

\footnotetext{
*Corresponding author: mohdfauzi@uthm.edu.my
} 


\section{Introduction}

Continuous improvement is planned, organized and systematic process of ongoing, incremental and company-wide change of existing practices to improve company performance. Continuous improvement is one of the core strategies for manufacturing excellent and is considered vital in today's business environment [1]. Continuous improvement has proved to be a useful way of business approach in centering low cost investment and high return improvements in both large, medium and small companies. Continuous Improvement method has become widely adopted as providing an important component for increasing company competitiveness. Continuous Improvement enables a company to be more successful in the pursuit of a specific strategy or set of objectives [2]. A well-known concept related to continuous improvement is Kaizen, which has its origin in Japan and means continuous change for the better by involving all employees [1]. Among the major potential benefits of continuous improvement are increased business performances and increased people performance [3][4].

Electrical and Electronic Industry is a leading sector in Malaysia's manufacturing sector, contributing significantly to the country's manufacturing output $(29.3 \%)$, exports $(55.9 \%)$ and employment (28.8\%) (MIDA - Malaysian Industrial Development Authority)[5]. Nowadays, a lot of manufacturers in Electrical and Electronic Industry, especially in production department have faced heighted challenges such as time constraint, quality issue, headcount issue, human issue and competition in market. No doubt, these manufacturers are always embracing changes and improvements in their key activities and processes to cope the challenges. With that, many companies have realized the importance of continuous improvement, no matter is self-improvement or company improvement [6]. The improvement of employees themselves will be able to enhance their discipline and their knowledge [7]. Meanwhile, the improvement of company can help the company to increase the quality and productivity, eliminating the waste and reduce the headcount problems [8][9].

The following research questions will be examined in the study:

i. What is the main Critical Success Factors (CSFs) in implementing continuous improvement?

ii. What are the tools of continuous improvement being used?

iii. What is the main barrier factor in implementing continuous improvement?

\section{Methodology}

The population is observed from Electrical and Electronic Industry in Bayan Lepas, Penang. The unit of analysis is organisation. There are total of 200 samples have been selected for this study. Random sampling is used for this research. Survey method was used in this research. Survey forms have been sent to the respondents through postal mail. Finally, 41 questionnaires were received for final study. It represented $20.5 \%$ of response rate. Statistical Package for Science Social (SPSS) was used to analyse the data being collected. Descriptive has been carried out to answer the research questions. 


\section{Analysis Results and Discussion}

\subsection{Cronbach's alpha}

Cronbach's alpha [10] was used to determine the reliability of the questionnaire as shown in Table 1. Cronbach's alpha is a measure of internal consistency, which able to determine how closely related a set of items are as a group. Accepted value for Alpha value is 0.7 [10].

Table 1. Cronbach's alpha result

\begin{tabular}{|l|c|c|c|}
\hline Variable & N & $\begin{array}{c}\text { No. of } \\
\text { items }\end{array}$ & Alpha value \\
\hline \hline Top Management Commitment & 10 & 5 & 0.753 \\
Training and Learning & 10 & 5 & 0.878 \\
Teamwork & 10 & 5 & 0.923 \\
Motivation & 10 & 5 & 0.798 \\
Resources Management & 10 & 5 & 0.764 \\
\hline \hline
\end{tabular}

\subsection{Normality Test}

Based on the Table 2, the normality value is 0.710 at $\mathrm{p}<0.001$, means that the distribution is normal distribution. Therefore, parametric test can be used.

Table 2. Normality Test

\begin{tabular}{|c|c|c|}
\hline \multirow{2}{*}{ Variable } & Shapiro-Wilk & \multirow{2}{*}{ Result } \\
\cline { 2 - 2 } & Significant & \\
\hline Practices of Factors & $0.710, \mathrm{p}<0.001$ & Normal Distribution \\
\hline
\end{tabular}

\subsection{Extent level of Continuous Improvement}

Five likert scale instrument has been used for final survey. Based on Table 3, training and learning had been rank as first. The mean score of training and learning is 3.9317. It is the highest factor. In reality, companies organized a lot of training program for their employees to enhance their knowledge. Without knowledge, employees will feel anxiety. Successful companies know that the more their employees learn about their jobs, the better they will become at every aspect of these jobs. Teamwork is ranked second important. Teamwork had contributed mean score about 3.7805. This followed by resources management, 3.7463 and top management commitment, 3.6341. Motivation is the least practiced factors, which only contributed about 3.3610. This may bring the meaning of employees were not motivated to improve their current job situation.

Table 3. Extent level of Continuous improvement

\begin{tabular}{|c|l|c|c|}
\hline & \multicolumn{1}{|c|}{ Factors } & Mean Score & Ranking \\
\hline F1 & Top Management Commitment & 3.6341 & 4 \\
\hline F2 & Training and Learning & 3.9317 & 1 \\
\hline F3 & Teamwork & 3.7805 & 2 \\
\hline F4 & Motivation & 3.3610 & 5 \\
\hline F5 & Resources Management & 3.7463 & 3 \\
\hline
\end{tabular}




\subsection{Application of Tools}

Based on the Table 4, lean manufacturing had high level of practices in companies among the 8 factors. The mean of degree of practices of lean manufacturing is 3.63. Lean Manufacturing is useful as well towards companies; mean score of degree of usefulness is 3.49. Instead of thinking ways to gain more profits, some manufacturers thinking to eliminate waste which also can save fund. For example, too much stock available in warehouse, it will increase the costs of storage. It should be ensure sufficient products available for customers. It is followed by ISO 9001, both the degree of practices and usefulness are rank as second. Its mean score for degree of practices is 3.41 and means for degree of usefulness is 3.32. Then, the third is FMEA. FMEA has 3.10 of the mean score for degree of practices and 3.07 of the mean score for degree of usefulness. Exceptional for the other tools, the seven-step problem solving is ranked as the seventh. The seven-step problem solving has the lower mean score for both degree of practices and degree of usefulness, which is 2.32 and 2.46. This maybe because of the processes are too tedious. Based on the means score in Table 4, Six-sigma had ranked as the fifth in both degree of practices and degree of usefulness. Means score for degree of practices is 2.63, which is lower than mean score of usefulness that is 2.78 . The difference of mean is 0.14 . This means that, employees found Six-sigma more useful than its being applied.

Table 4. Application of Tools

\begin{tabular}{|l|l|c|c|c|c|}
\hline & \multicolumn{1}{|c|}{ Tools } & \multicolumn{2}{c|}{$\begin{array}{c}\text { Mean } \\
\text { of Practices }\end{array}$} & \multicolumn{2}{c|}{$\begin{array}{c}\text { Mean } \\
\text { of Usefulness }\end{array}$} \\
\hline T1 & The Seven-Step for Problem Solving & 2.32 & $(7)$ & 2.46 & $(7)$ \\
\hline T2 & Fish Bond Diagram & 2.46 & $(6)$ & 2.49 & $(6)$ \\
\hline T3 & Six-Sigma & 2.63 & $(5)$ & 2.78 & $(5)$ \\
\hline T4 & Lean Manufacturing & 3.63 & $(1)$ & 3.49 & $(1)$ \\
\hline T5 & Failure Mode and Effect Analysis (FMEA) & 3.10 & $(3)$ & 3.07 & $(3)$ \\
\hline T6 & Quality Control Circle (QCC) & 2.98 & $(4)$ & 2.88 & $(4)$ \\
\hline T7 & ISO 9001 & 3.41 & $(2)$ & 3.32 & $(2)$ \\
\hline T8 & Others & 0.24 & $(8)$ & 0.32 & $(8)$ \\
\hline
\end{tabular}

Problems faced in Implementing Continuous Improvement have been evaluated based on 5 likert scale instrument. The result based on Table 5, there are two main causes of the problems in implementing continuous improvement are lack of budget and lack of worker commitment. It is normally difficult to get financial support and approval from top management. Top management only invests some programme that is profitable to the company. It is no doubt that, top management treat continuous improvement as an optional program. They may postpone continuous improvement program when there are a lot of workload. From the Table 5, it is obviously to know that, among forty-one respondents, there are only four continuous improvement members. Most of the respondents are engineer. This means that, engineers not only play their role as engineers, they also take part in continuous improvement activities. They need to finish their own job, at the same time; they need to help company to continuous improve to have better performance and more profitable. Most of the employees do not commit much in continuous improvement program due they do not have extra times and rewards. Employees' motivator is money or any other material wealth. It is important for top management to recognize their hard work. 
Table 5. Problems faced in Implementing Continuous Improvement

\begin{tabular}{|l|l|l|l|}
\hline & Barrier Factor & Mean Score & Ranking \\
\hline B1 & Failure to understand how change happen & 3.32 & 7 \\
\hline B2 & Lack of top management commitment / support & 3.20 & 11 \\
\hline B3 & Ego & 3.21 & 10 \\
\hline B4 & Employees resists changing & 3.27 & 8 \\
\hline B5 & Lack of time & 3.46 & 3 \\
\hline B6 & Lack of budget & 3.51 & 1 \\
\hline B7 & Lack of knowledge & 3.37 & 5 \\
\hline B8 & Lack of training & 3.37 & 5 \\
\hline B9 & Lack of worker commitment & 3.51 & 1 \\
\hline B10 & Lack of resources & 3.20 & 11 \\
\hline B11 & Lack of measurement & 3.22 & 9 \\
\hline B12 & Lack of focus action & 3.44 & 4 \\
\hline
\end{tabular}

\section{Conclusion}

Survey result shows that teamwork and training and learning are respectively the importance factor and the most practices factor in Electrical and Electronic Industry. Most of the Electrical and Electronic Industry emphasis is on using Lean Manufacturing as the tool of continuous improvement practices. Besides that, Electrical and Electronic Industry faced the problems of lack of budget and lack of worker commitment.

\section{Acknowledgements}

Appreciation to MOHE and ORRIC, Universiti Tun Hussein Onn Malaysia for supporting this research (Geran Kontrak, Vot: U429). Appreciation also to Manufacturing Technology Management (MTM) focus group, Faculty of Technology Management.

\section{References}

[1] M. F. Ahmad, N. Zakuan, a Jusoh, Z. Tasir, and J. Takala, "Meta-analysis of the relationship between TQM and Business Performance," IOP Conf. Ser. Mater. Sci. Eng., vol. 46, no. 1, p. 12020, 2013.

[2] M. F. Ahmad, R. Z. R. Rasi, N. Zakuan, M. . Haji-Pakir, and J. Takala, "The Impact of ASEAN Free Trade Agreement as Moderator on TQM Performance Model in Malaysia: Survey Result,” Soc. Sci., vol. 11, no. 12, pp. 2932-2937, 2016.

[3] M. F. Bin Ahmad and S. M. Yusof, "Comparative study of TQM practices between Japanese and non-Japanese electrical and electronics companies in Malaysia: 
Survey results," Total Qual. Manag. Bus. Excell., vol. 21, no. 1, pp. 11-20, 2010.

[4] M. F. Ahmad, M. S. M. Arif, N. Zakuan, S. S. S. A. Rahman, T. A. R. Abdullah, and N. Fadzil, "The Effect of Demographics on Customer Satisfaction amongst Malaysia Hajj Pilgrims: Survey Result," Appl. Mech. Mater., vol. 660, pp. 10001004, 2014.

[5] M. F. Ahmad, M. S. M. Arif, N. Zakuan, S. Rahman, M. Latif, and M. Khalid, "The Mediator Effect of Customer Satisfaction between Quality Management Practices and Communication Behavior amongst Malaysia Hajj Pilgrims: Survey Result," Appl. Mech. Mater., vol. 660, no. 2015, pp. 1005-1009, 2015.

[6] M. F. Ahmad, N. Zakuan, R. Z. R. M. Rasi, M. N. N. Hisyamudin, and J. Takala, "Mediator effect of total productive maintenance between total quality management and business performance: Survey result in Malaysia automotive industry," Adv. Sci. Lett., vol. 21, no. 12, pp. 3723-3725, 2015.

[7] M. F. Ahmad, M. S. M. Ariff, N. Zakuan, M. Z. M. Saman, S. S. S. A. Rahman, T. A. R. Abdullah, and N. Fadzil, "The effect of demographics on quality management principles of ISO 9001:2008 amongst Malaysia Hajj Pilgrims,” Soc. Sci., vol. 11, no. 11, pp. 2748-2752, 2016.

[8] M. F. Ahmad, N. Zakuan, A. Jusoh, S. M. Yusof, J. Takala, and M. S. M. Arif, "Comparative Study of TQM Practices between Japanese and Non-Japanese Companies: Proposed Conceptual Framework," Adv. Mater. Res., vol. 903, pp. 371-377, 2014.

[9] M. Ahmad, N. Zakuan, J. Ahmad, and J. Takala, "Meta-analysis of the TQM impact on business performance amongst regions and countries," Int. J. Ind. Syst. Eng., vol. 20, no. 2, pp. 155-164, 2015.

[10] J. C. Nunally, Psychometric Theory, Second ed. New York: McGRAW-HILL, 1978. 